\title{
LA FORMACIÓN DISCURSIVA TRASCENDENTALISTA EN LA POESÍA COSTARRICENSE CONTEMPORÁNEA
}

\author{
Francisco Rodríguez Cascante
}

\begin{abstract}
RESUMEN
En este artículo propongo la existencia de una formación discursiva trascendentalista en el eje diacrónico de la poesía costarricense. El objetivo del trabajo es el estudio de esta constante discursiva en la poesía contemporánea, especialmente la producida después de 1980, no sin dejar de lado la mostración de esta poética en la lírica anterior a esa década. Por esta formación discursiva entiendo grupos líricos donde: a) en el eje nivel enunciativo se evidencia la presencia de enunciados monódicos de carácter figurativo y abstracto; b) observando el nivel representacional, son conjuntos donde se construyen espacios autónomos de condición aurático-esencialista. Por otra parte, argumento que el sustancialismo metafísico asumido por esta formación discursiva se ha consolidado en el campo cultural literario nacional gracias a los modelos clasificatorios históricamente legitimados en las literaturas occidentales, los cuales han contribuido a sustentarlo mediante un proceso de fetichización institucional de la producción artística, en su asociación con la dimensión aurático-sustancial de la estética.
\end{abstract}

Palabras clave: Literatura costarricense, formación discursiva, historiografía literaria, poesía trascendentalista, siglos XIX, XX y XXI.

\begin{abstract}
In this article I propose the existence of a transcendentalist discursive formation in the diachronic trajectory in the Costa Rican poetry. The goal is to study the presence of this type of discourse in contemporary poetry, in particular that produced after 1980, without ignoring the evidence of this poetry in the lyric preceding that decade. Such a discursive formation is taken to include lyric groups in which: a) at the enunciative level one can see the presence of monodic enunciations with a figurative and abstract nature, b) the representational level consists of groups in which one can construct autonomous areas of an auratic-essentialist condition. I also argue that the meta-physical sustantialism assumed in this discursive formation has consolidated in the national cultural literary field thanks to the classification models historically legitimated in the Occidental literary works; these have contributed to maintaining it via an institutional fetishization process in the artistic production, in its association with the auratic- substantial dimension of aesthetics.

Key words: Costa Rican literature, discursive formation, literary historiography, transcendental poetry, XIX, XX, and XXI centuries.
\end{abstract}

Dr. Francisco Rodríguez Cascante. Catedrático en la Sede de Occidente de la Universidad de Costa Rica. Subdirector del Centro de Investigación en Identidad y Cultura Latinoamericanas (CIICLA) de la Universidad de Costa Rica. Correo electrónico: rodriguezcascante@yahoo.com

Recepción : 03- 5- 2007

Aprobación : 16- 6- 2007 


\section{La fetichización de una práctica literaria}

En su Poesía española, ensayo de métodos y límites estilísticos (1952), Dámaso Alonso intenta explicar el concepto de "intuición totalizadora", y realmente le resulta difícil porque es un ámbito que escapa a la lógica racionalizadora. Nos dice que se trata de una suma de intuiciones parciales, la cual se eleva sobre aquellas, y que es, igualmente, inexpresable e inefable. Al procurar aclarar con un ejemplo, menciona la poesía de Dante como una gran blancura y propone una lectura de un soneto de la Vita Nuova, donde la imagen de la mujer, de acuerdo con Alonso, corresponde a una iluminación de blancura, una imagen total de la pureza: "Es un ámbito -el alma sabe que es un ámbito milagroso-, es una luz blanca" (1951: 44).

Este irracionalismo esencialista se constituyó, a partir del criterio platónico de la posesión divina ${ }^{1}$, en una gramática discursiva que ha procurado históricamente dar sustento teórico-crítico a lo que Walter Benjamin denominó el aura de la producción artística, es decir el carácter particular y el "sentido original" que las culturas occidentales le otorgaban antes del surgimiento de las técnicas de reproducción mecánica y de la legitimación de la industria cultural'; ello en conexión directa con una concepción bellaletrística del "autor/ genio, poseedor del saber y artífice de la lengua" (Bolaños 1996: 62), y del texto como objeto de contemplación.

Pero dicho sustancialismo metafísico difícilmente se hubiera podido afirmar como formación discursiva de carácter diacrónico en la práctica lírica, de no ser por su asentamiento en un campo cultural donde los "esquemas clasificatorios históricamente constituidos" (Bordieu 1995: 486) en las literaturas occidentales lo sustentaran socialmente y lo constituyeran, como ha ocurrido, en un fetiche gracias a la institucionalización de los campos literarios y a la producción, como indica Bordieu, de sus formas específicas de $i l l u s i o^{3}$.

Antes que en la literatura en general, la fetichización ha sido un fenómeno mayormente acentuado en la figura del poeta y de la "creación lírica". Gracias a esas reglas de la illusio propias de las configuraciones de los campos literarios, este fenómeno ha sido una constante en una formación discursiva de la poesía costarricense (formación en tanto constante no lineal en el eje diacrónico de la producción lírica nacional), la que llamo trascendentalista, fenómeno que sigue vigente en la poesía contemporánea.

Con la finalidad de analizar el funcionamiento de las regularidades discursivas referidas a textos literarios, en un artículo reciente propuse que

\footnotetext{
Para estudiar objetivamente las formaciones discursivas, y en un momento que ha visto agotarse las pugnas por la hegemonía simbólica de los movimientos ideológicos oposicionales, -las fuerzas de atracción de la exterioridad- es imperativo realizar un camino inverso: de las semiosis centralizadoras político-institucionales a los mecanismos textuales de asentamiento -instalación provisional, con vocación expropiativa y redistributiva- de la formación discursiva, cuya variabilidad histórica está determinada tanto por fenómenos de mediación extratextuales como por estructuras expresivas que ingresan en tanto modelos enunciativos.

Estimo que los mecanismos textuales de asentamiento con mayor fuerza semiótica para direccionar los vectores espacio-temporales de la formaciones discursivas son la función autoral, las posiciones enunciativas y las estrategias representacionales. Estos mecanismos a la vez que aglutinan las regularidades, posibilitan movimientos centrífugos de transición discursiva (Rodríguez Cascante 2007. En prensa).
}

Considero que los últimos dos mecanismos textuales de asentamiento son los que dan luz a la hora de conceptualizar la formación discursiva trascendentalista. Con base en ellos, propongo entenderla como aquella producción lírica que integra los siguientes postulados: 
a) En primer lugar, en el nivel enunciativo, se trata de enunciados monódicos de carácter figurativo y abstracto.

b) En segundo lugar, en la dimensión representacional, se construyen espacios autónomos de condición aurático-esencialista.

En lo que sigue, me dedico a estudiar, primero, las marcas de esa formación discursiva en el período 1890-1980 de la poesía nacional y, después, muestro la continuidad de esa formación en la lírica publicada posterior a 1980.

\section{Las huellas del trascendentalismo en la poesía costarricense}

La formación discursivo trascendentalista se remonta a los primeros textos poéticos costarricenses y está presente en todo el eje diacrónico de la poesía nacional, de manera diferenciada, constituyéndose en un polisistema literario que atraviesa las corrientes ideológicas y estéticas de los textos. Este eje se constata ya en los autores de la Lira Costarricense (1890), por ejemplo en Juan Diego Braun.

Siguiendo la misma dimensión esencialista a la que se adhiere Dámaso Alonso al imaginarse a la mujer del soneto de Dante, el poema "La mujer" de Braun define en términos totalizadores: "La mujer es una flor/ A que el cielo da su esencia, / Que embriaga nuestra existencia/ Con el perfume de amor" (1990: 58). Antes que sujeto histórico, la feminidad es comprendida como belleza y fragilidad (luz en la interpretación de Alonso), además de objeto de consumo y placer. Pero no solo esto, sino también -y aquí se plantea una vinculación con el efecto de fetichización al que hacía alusión anteriormente- instrumento donde el poeta se comunica con los dioses, en un acto que "eleva" la escritura poética a lo trascendente: "Dulce niña, en conclusión, / Es la fuente la mujer/ Do el poeta va á beber/ La divina inspiración" (1990: 60-61).

Esta formación discursiva se consolida con la poética modernista, especialmente con los textos de Roberto Brenes Mesén. Claro ejemplo de ello es el poema "Envío" del libro En el silencio (1907), donde, desde el punto de vista enunciativo se presenta la invocación en segunda persona empleando un léxico figurado exotista. En el espacio representacional, es el aura de la condición estética, asociado a la pureza de la "verdad", el que se ofrenda como compensación superior a la pérdida material. El texto propone, entonces, la dicotomía materialidad/espiritualidad insistiendo en la relevancia del segundo componente:

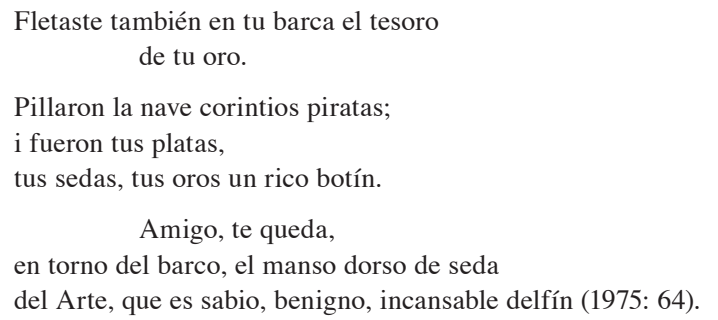

Tal poética se continúa perfilando mejor en su dimensión representacional en el poemario siguiente del autor, Hacia nuevos umbrales (1913). Un texto de este libro, "Rumor", enuncia elementos claves del trascendentalismo: el arte es un más allá de lo humano y se expresa por medio de un lenguaje figurativo. 


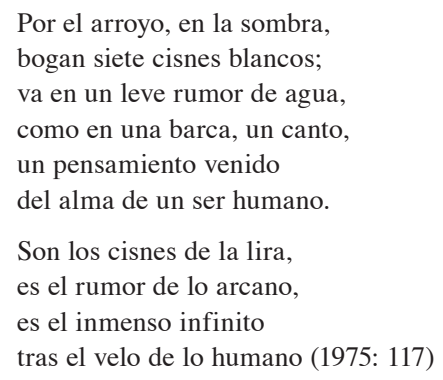

Tras el tono reclamativo anclado en elementos léxicos tópicos del modernismo y de expresión lírica antigua (“cisnes, lira”), se representa mediante sinécdoque, la metafísica de la estética, allende la materialidad de la existencia.

Un poema paradigmático en la poesía costarricense que igualmente propone estas mismas certidumbres es "Vuelo supremo" del poemario Alas en fuga (1941) de Julián Marchena, el cual separa dos realidades: la terrenal y la esencial:

\footnotetext{
Huir de todo lo que sea humano;

Embriagarme de azul...Ser soberano

De dos inmensidades: mar y cielo (1973: 48).
}

Es un claro intertexto de Baudelaire; este autor francés compara la figura del poeta con la del albatros: en tierra es feo y torpe, mas en vuelo es diestro y bello ${ }^{4}$. Igual hace Marchena: es "esencial" la fuga de la materialidad; antes que el habitus humano importa la huída hacia horizontes supremos donde estarían los auténticos valores.

Ya a mediados del siglo XX, de la misma manera, el enunciador lírico del poemario Alto sentir (1953) de Alfonso Ulloa Zamora, expresa ese deseo de superar la especificidad humana como objetivo del "ser verdadero". Así lo manifiesta el poema de revelador título "Tránsito al ser": "Ser en todo, no en mí,/ como es el árbol/ simplemente un pedazo de universo" (1982: 35). Esta metafísica de la existencia se basa en la illusio que posibilita pensar una separación entre el sujeto y su realidad material y social.

En concordancia con las razones y los ejemplos recién expuestos, Carlos Cortés afirma que "[e]sta característica marcará para siempre el modelo de representación poético costarricense: poesía será una distancia formal entre la realidad y su expresión” (1999: 38), y equipara dicho nivel con la distancia ideológica que mantiene el costarricense ante su realidad, lo cual implica, en esta arriesgada generalización, un determinismo homogeneizante del sujeto nacional: "Es la huida, la fuga de la historia" (1999: 38). Esto es válido para esta formación discursiva, en el entendido de que el esencialismo es también, una manera de entender e interpretar la realidad.

Dicho escape de la materialidad del mundo cotidiano, constituye igualmente una constante discursiva en la poesía de Eunice Odio, presente con mucho énfasis en los recodos hierofánicos de su Tránsito de fuego (1957), donde la elaboración mitológica de un universo hermético es la dimensión representacional pretendida, mediante enunciados altamente figurativos que echan mano de múltiples intertextos clásicos (Ion es uno de sus personajes centrales). Por ejemplo, la tradición retórica de la rosa como arquetipo de la estética en la III sección de "Integración del elemento paterno" de la I parte: 


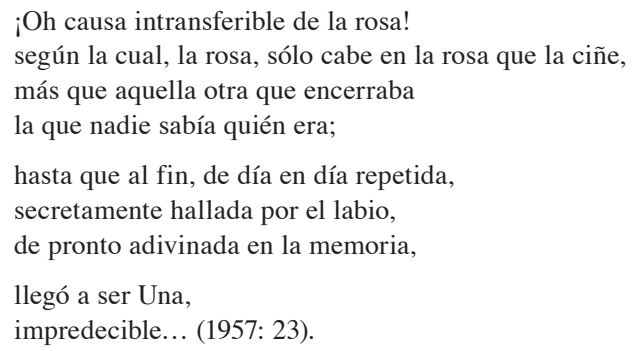

Justamente, en la afirmación de esta formación discursiva radicó la fundación de la poesía contemporánea costarricense, entendiendo por ella la que se vinculó con el vanguardismo y cuyas publicaciones aparecieron en los años cincuentas. En el más completo estudio de este período: La imagen separada (1984) de Carlos Francisco Monge, afirma su autor que dicha producción poética nació en una contradicción con la historia. Refiriéndose a los escritores de ese momento, afirma Monge que "Más bien, prefirieron interpretar su historia y sus experiencias con una práctica literaria que poco tenía que ver con aquellas reformas y transformaciones a las que aspiraban. [...] La respuesta a esta manera de vincularse con el mundo ha sido la preocupación por la definición y examen del ser y su condición" (1984: 37). El título del capítulo segundo del estudio es revelador: "La búsqueda ontológica", donde analiza los textos de Cardona Peña e Isaac Felipe Azofeifa como iniciadores de esta expresión, y al grupo que llama Monge solipsista, aquellos que mayormente se vincularon con el surrealismo: Ricardo Ulloa Barrenechea, Mario Picado, Jorge Charpentier y Carlos Rafael Duverrán.

Una variante enunciativa de la formación discursiva que analizo es aquella que alejándose de la illusio morfosintáctica del modernismo y de la metafísica deífica, se basa en la experimentación formalista y se acerca al vanguardismo, para procurar la construcción de mundos lingüísticos autónomos y de una dimensión representativa irracional, queriendo dar espacio al caos como universo poético. Un caso de esta naturaleza lo propone Alfredo Cardona Peña en su Asamblea plenaria (1976), donde la enumeración galopante es la que pretende un universo representacional aurático: "Esfera de círculos-oxígenos,/ plenitud de ojos, alas, espacios,/ ángeles gigantescos retratados por Dante/ qué son sino adecuaciones de mentes/ a suceso cósmico, éxtasis, labios temblando" (1981: 140).

De la misma manera, el poemario Vigilia en pie de muerte (1961) de Isaac Felipe Azofeifa asume del existencialismo la soledad como condición esencial del ser humano frente a una realidad exterior que lo expulsa al aislamiento y a la angustia. Así lo expresa el poema "Torre de silencio":

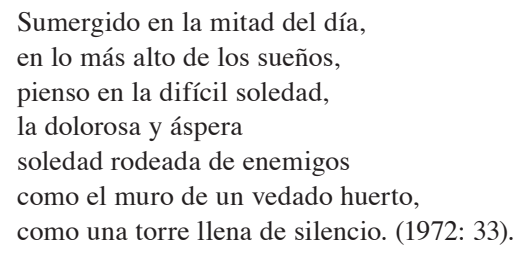

Ese solipsismo ontológico del que habla Monge, está presente por igual en el poemario Ángel del camino (1970) de Ricardo Ulloa Barrenechea donde la enunciación hermética remite a la contemplación del tiempo como trascendencia e inefabilidad: "Esta voz que siendo mía/ suena a río,/ musgo perfumado. /Ondas misteriosas/ con que hablamos/ a una eternidad instante" (1970: 5). 
Asimismo aparece en la enunciación surrealizante de Demonio en caos (1972) de Ana Antillón. Aquí, en un trabajo semejante al de Cardona Peña por su dimensión experimental, es la feminidad que vuelca en la complejidad metafórica de las oposiciones conceptuales, la representación de una subjetividad que expresa su mundo interior como contradictoria sustancia iluminada: "Este cansancio, el alma descompuesta/ que se columbra en Mundo/ con su despacio errar por carga edades, la luminosa esencia ya traspuesta/ al difícil profundo" (1972: 71).

Una nueva variación de esta formación discursiva es la poesía religiosa, donde la enunciación textual de carácter figurativo se constituye en andamiaje para mostrar la participación divina en la vida cotidiana, como en Diferente al abismo (1955) de Jorge Charpentier: "Si Dios se llamara gota,/ tú y yo, y el modo de llamarnos/ nos haríamos agua, y no / comprenderíamos el ahogo último" (1989: 45). Así como también deviene en plegaria para la comunicación con la trascendencia, tal como se presenta en Después de nacer (1967) de Rodrigo Quirós:

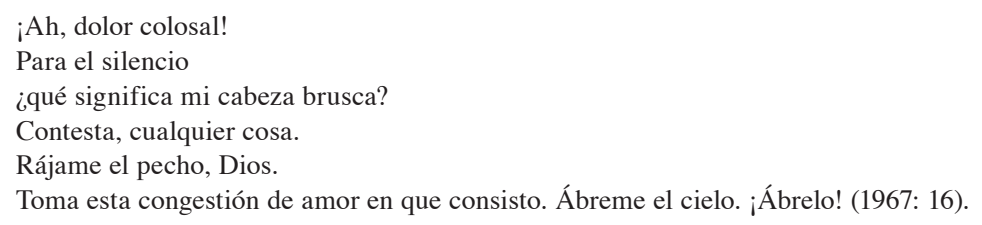

Refiriéndose a los poetas de los años 60 y 70, afirma Carlos Francisco Monge que el realismo poético por ellos practicado no implicó la superación de esa contradicción con la historia manifestada por los autores de los 50: "Si por una parte se mostró un instinto por renovar y remozar poéticamente los modos de abordar la realidad, por otra empezó a emerger una irreconciliable lucha contra el estado de cosas histórico" (1984: 49). Y es que, me parece, aparte de Debravo, quien desarrolló una poesía conversacional muy historizante, los demás autores del período que escribieron dentro de la formación discursiva trascendentalista (Laureano Albán, Julieta Dobles, Alfonso Chase, Rodrigo Quirós) siguieron en la dirección solipsista de la poesía de los años $50^{5}$. Esto explica la idea de "ambigüedad ideológica" que vincula Monge con esta poesía.

\section{El Manifiesto trascendentalista}

El mayor esfuerzo de sistematización teórica de esta formación discursiva lo constituye el Manifiesto trascendentalista publicado en 1977 por Laureano Albán, Julieta Dobles, Ronald Bonilla y Carlos Francisco Monge. Este texto programático realmente no presenta mayor novedad, en sus fundamentos, sobre los planteamientos que sobre la poesía ya se habían realizado desde Platón hasta Dámaso Alonso y la estilística de los años 50. Quizá esto explique la poca acogida que tuvo y la indiferencia con que se mira en la actualidad ${ }^{6}$.

Se trata, en primer lugar, de una reacción y una cura en salud contra la poética conversacional que estaba escribiéndose en Centroamérica durante las décadas del 60 y el 70: "Casi todas las tendencias de la poesía contemporánea [...] atentan contra las características originarias de la poesía” (1977: 17). Este supuesto, maneja una concepción ahistórica del fenómeno poético de claras resonancias platónicas: "La poesía como un acto trascendental, como una experiencia especial que contiene y trasciende la experiencia cotidiana del hombre" (1977: 29). Asimismo, el texto establece unos orígenes divinos de la poesía, remontándola 
hasta "los profetas y los cantos religiosos de la antigüedad"7 (1977: 23). Así pues, en esta concepción el texto, cuyos componentes son imágenes figuradas, se manifiesta una noción de trascendencia de aristas irracionales: "Exponer la clara concepción de la poesía trascendental, es necesariamente inadecuado e insatisfactorio, porque el hecho en sí sólo logra darse plenamente en la vivencia del poema por el lector" (1977: 54).

Por otra parte, el autor un ser especial capaz de alcanzar la intuición trascendental mediante el empleo del lenguaje figurado. En el Manifiesto se hace una separación caracterológica entre profesiones: la distinción entre el matemático y el poeta como sujetos diferenciados; pero ya cuatro años antes de la publicación del documento que analizo, Laureano Albán, en un texto titulado “iLa estúpida poesía!” -publicado en la antología de Carlos Rafael Duverrán Poesía contemporánea de Costa Rica (1973)- hacía la diferencia entre el escritor y el poeta ${ }^{8}$, enfatizando en la capacidad lumínica de la poesía como oficio superior.

El lector y el proceso de lectura ocupan igualmente definiciones esencialistas en el Manifiesto; el primero es aquel sujeto capaz de captar mediante su intuición trascendental la misma vivencia que produjo el poeta. De esta forma, la lectura viene a ser la transmisión de vivencias trascendentales “directamente de ser a ser" (1977: 83):

Pero el lenguaje figurado no es más que una potencialidad, un determinado uso del aparato lingüístico, por lo que para su combinación en imágenes adecuadas a la vivencia trascendental, el poeta recurre a la imaginación creadora, la que posibilita las imágenes que por la relación de sus símbolos, sus sonidos, sus significados, sus insinuaciones temáticas, todo ello en un movimiento abierto de asociaciones, logra producir en la intuición trascendental del lector una vivencia equivalente, semejante, dentro de un margen adecuado de identidad temática. (1977: 77-78).

\section{El trascendentalismo en la poesía posterior a 1980}

La práctica literaria de los autores del Manifiesto, ha procurado seguir, sin que ello signifique un camino homogéneo, las ideas del documento. Sin dudas ha sido Laureano Albán el más apegado a la poética expuesta en todos sus libros 9 . Tomando en consideración la fecha propuesta, Albán publica en 1980 Herencia del otoño, un poemario escrito en España y dedicado a los poetas españoles. "Tránsito del hombre" es un poema dedicado a Vicente Aleixandre , y desde el punto de vista enunciativo está construido con un abigarrado lenguaje figurativo de carácter declamativo y abstracto, que da pie a la representación del camino humano, un universo de claras resonancias auráticas, símbolos del devenir del ser: "De dios en dios invoca lejanías,/ ceremonias tatuadas de misterios,/ danzando junto al éxtasis del fuego/ que presta su calor para el milagro" (1980: 71).

Esta misma construcción se observa en poemarios más apegados a historicidades concretas como Geografía invisible de América (1982) y El viaje interminable (1983), este último dedicado al proceso de la conquista y colonización de América. Por ejemplo, el poema "Llevaban la palabra" en el nivel enunciativo marca la abstracción mediante metáforas herméticas y en el plano representacional, la ambigüedad es a lo que remite el significante: "Que todo lo llevaban/ entre olvido y palabra;/ ahí, en esa zona/ de lo diáfano y diario,/ entre esa mansedumbre/ de tactos apagados/ que es la mano en el tiempo" (1983: 24).

En este mismo nivel de abstracción enunciativa, el texto Ecos (1993) de Ricardo Segura asume la representación del tiempo como lugar aurático-metafísico donde se debaten la 'fuerzas superiores' del universo: "Palpita/ el tiempo como un corazón tan arrogante que hiciese abluciones de inocencia,/ que hiciese Verbo al devenir,/ impulsando la sangre ofrecida en matices al Cosmos tremendo" (1993: 43). 
En textos de Milton Zárate -Al final de la memoria (1991), La extensa huida (1990), Confesiones del olvido (1991) y Aun desde la lluvia (2003)- el trascendentalismo se afirma con un trabajo acucioso de formalización enunciativa ${ }^{10}$. Los dos niveles señalados como definitorios de esta formación discursiva se evidencian en la mayor parte de los poemas del autor, como en el último poemario, dedicado a la temática de la maternidad, donde el hablante lírico exalta el proceso de engendramiento y cuidados hacia el hijo, y le rinde homenaje a la figura materna: "Madre de todos los soles repartidos/ sobre la corola virginal/ de la tristeza./ Aún puedo beber tu rostro/ desde una copa vencida,/ el ayer siempre interrumpe despedidas" (2003: 102).

La variante amatoria de esta formación discursiva recurre a la declamación de enunciados monódicos de carácter figurativo y abstracto, que pretenden expresar sentimientos íntimos de vacío y necesidad en el plano representacional. Ejemplo de ello es el segundo poema de la II parte de Contracanto (1981) de Diana Ávila: "busco un amor distinto/ una contaminación profunda/ una suciedad de mar en los pulmones/ una boca que maltrate el silencio/ otra ternura" (1981: 28).

Los textos de Julieta Dobles proponen otro registro de acercamiento a la lírica trascendentalista. Si bien en el nivel enunciativo comparten la dimensión figurativa del lenguaje, en el espacio representacional se distancia de la construcción abstracta de universos simbólicos, accediendo más bien a mundos auráticos anclados en realidades históricas tangibles y cercanas. Por ejemplo, el poema "Ascensión al templo" de Una viajera demasiado azul (1990) elabora una metáfora del Muro de los Lamentos de Jerusalén: "Las piedras amarillas, como luces sombrías/ recogieron entonces el reflejo del miedo,/ y la humedad del llanto/ en los rostros de los últimos fugitivos,/ que desde el muro empiezan cada noche/ su exilio de milenios" (1993: 41-42). Igual tratamiento enunciativo y representacional aparece en el abordaje de otras temáticas, como la feminidad, en Los delitos de Pandora (1987).

Otra modulación del trascendentalismo lo constituye la poesía de Carlos Francisco Monge. En sus últimos textos -La tinta extinta (1990), Biografía de unas palabras (2000) y Enigmas de la imperfección (2002)- su preocupación por el fenómeno metapoético se vuelve central ${ }^{11}$. Dicha reflexión se desarrolla mediante una escritura que mezcla los dos niveles de la poética trascendentalista con elementos comparativos de la cotidianidad. Un caso de esto lo constituye el poema “Oficio de poesía” de Enigmas de la imperfección, donde propone el enunciador, en clara referencia a la formación discursiva objeto de estudio, que la poesía es luz, pero inserta matices referenciales concretos: "sino clara y celosa, / como loba guardando de sus crías, inquieta, /como el vals, la mazurca/ y el yigüirro obstinado de la madrugada" (2002: 46).

La poesía de Ronald Bonilla, otro de los firmantes del Manifiesto, atiende a los dictados hechos en el documento de 1977, por cuanto despliega significativamente la exigencia de un lenguaje figurativo y, por ejemplo, en su poesía amatoria, da cabida a la construcción comparativa que posibilita la referencialidad de lo histórico a lo metafísico. Esto se evidencia en el poema "XXVII (Señales)" de Porque el tiempo no tiene sombra (2001): "Debajo nos asimos/ como fantasmas olvidados,/ y volvemos a preguntar/ sobre la marcha,/ como disparando hacia el milagro,/ haciendo blanco sólo/ en los puntos ignotos/ de tanta huída." (2001: 73).

Por otra parte, la poética trascendentalista procura integrar el sentimiento amoroso a las fuerzas esenciales de la naturaleza, como en "El encuentro", texto de Cantares de la tierra (1986) de Gabriela Chavarría: "Dimensiones y niveles,/ de lo telúrico a lo cósmico ascendían/ y del cosmos bajaban a la tierra./ Yo desconocía la ruta/ de tu amor" (1986: 15). Este plano declamatorio en la enunciación abstrae lo cotidiano para conceptualizarlo, en el nivel representacional, en tanto trascendencia ${ }^{12}$. 
La enunciación monódica se une al énfasis declamatorio y abstracto en el poemario Penumbra de la paloma (1999) de Laura Fuentes, donde en el poema "Navegante" el sentimiento amoroso se torna deseo de la voz lírica: "Algún día/ seré el malecón/ donde tu esencia/ perfume embarcaciones/ de sabios pescadores" (1999: 41).

La experiencia amorosa es positiva en este texto de Fuentes, al igual que en "Apocalipsis" de Vientre de ocarina (2005) de Vivian Cruz, donde el amor se equipara con la luz y la comunicación implica unión afectiva y corporal: "Bajaremos la luz/ un poco/ acercaré/ mi nerviosa cabellera/ hacia tus manos" (2005: 93).

Si bien en estos poemarios de Fuentes y Cruz se evidencian con claridad los dos elementos conformadores de la poética trascendentalista, en la producción de Alejandra Castro -Desafío a la quietud (1992), Loquita (1997), Tatuaje giratorio (1999), Hay milagros peores que la muerte (2002) y No sangres (2005)- a estos aspectos se agrega un acendrado hermetismo, tan definitorio de la lírica de Albán, Segura y Zárate. En "La estación del éxodo" de Hay milagros peores que la muerte, la enunciación de carácter autotélico describe los sentimientos de la voz lírica y construye un enunciatario para esbozarle su representación de sí misma, un sujeto asilado, distante y abstracto:

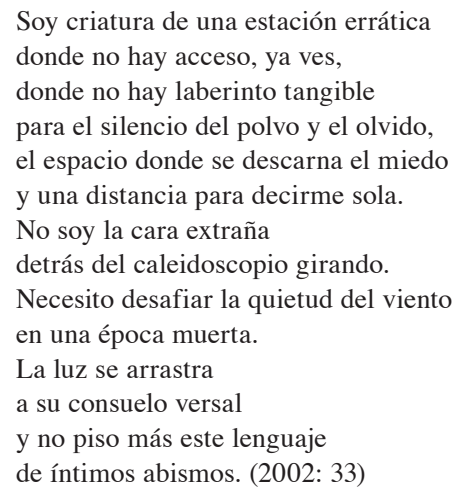

A estas imágenes de soledad y silencio en la construcción del retrato poético, se suma en el texto "El miedo" de No sangres, el sentimiento de fracaso y el terror por la existencia y la relación amorosa: "Perdí el interés por el fin / de mi fracaso. /Transito el miedo." (2005: 39). La experiencia de la soledad, el fracaso y la incomunicación son también tópicos de esta poesía trascendentalista escrita a comienzos del siglo XXI.

\section{Conclusión}

Este trabajo ha tenido como objetivo dar cuenta de la existencia, a nivel diacrónico, en la poesía costarricense, de una formación discursiva trascendentalista. Propuse, al inicio del estudio, que por ello entiendo dos niveles: primero, considerando el eje enunciativo, se trata de grupos textuales donde se evidencia la presencia de enunciados monódicos de carácter figurativo y abstracto. Segundo, y observando el eje representacional, son conjuntos líricos donde se construyen espacios autónomos de condición aurático- esencialista.

Asimismo, señalé que el sustancialismo metafísico asumido por la formación discursiva se ha consolidado en el campo cultural literario nacional gracias a los modelos clasificatorios históricamente legitimados en las literaturas occidentales, los cuales han contribuido a sustentarlo mediante un proceso de fetichización institucional de la producción artística, en su 
asociación con la dimensión aurático-sustancial de la estética. Ha sido este eje de legitimación el que ha creado, a partir de la tradición literaria occidental, formas concretas de illusio para esta formación discursiva. Estos procesos de legitimación han estado sustentados por la asociación de la producción lírica, a partir de Platón, con la divinización de la figura del poeta y de su posesión, como condiciones (sobre) naturales para la "creación” de la poesía.

Esta modalidad de textualización ha sido (y lo sigue siendo) una formación discursiva en la historia literaria costarricense porque se ha mantenido vigente como paradigma poético desde la misma fundación de la lírica nacional con la antología Lira costarricense (1890), atravesando el eje diacrónico en textos producidos, entre otros, por Roberto Brenes Mesén, Julián Marchena, Eunice Odio, Ana Antillón, Rodrigo Quirós, hasta la poesía posterior a 1980: Laureano Albán, Ricardo Segura, Carlos Francisco Monge, Laura Fuentes y Alejandra Castro.

En esta primera década del siglo XXI, la poética trascendentalista sigue siendo un importante referente para la práctica de la escritura lírica, gracias a su asentamiento enunciativo, su legitimación referencial y sus modelos de producción históricos.

\section{Notas}

1. En "Ion o de la poesía", por medio de Sócrates, el filósofo funda la concepción intuitivo-trascendentalista y aurática de la producción poética: “[...] el poeta es un ser alado, ligero y sagrado, incapaz de producir mientras el entusiasmo no le arrastra y le hace salir de sí mismo. Hasta el momento de la inspiración todo hombre es impotente para hacer versos y pronunciar oráculos. [...] El objeto que Dios se propone al privarles del sentido y servirse de ellos como ministros, a manera de los profetas y otros adivinos, tengamos inspirados, es que, al oírles nosotros, tengamos entendido que no son ellos los que dicen cosas tan maravillosas, puesto que están fuera de su buen sentido, sino que son los órganos de la divinidad que nos hablan por su boca." (1984: 98).

2. Véase al respecto Walter Benjamin. "The Work of Art in the Age of Mechanical Reproduction". Iluminations: Essays and Reflections. New York: Schoken Books, 1968: 217-251.

3. Señala el autor: "Cada campo (religioso, artístico, científico, económico, etc.), a través de la forma particular de regulación de las prácticas y de las representaciones que impone, of rece a los agentes una forma legítima de realización de sus deseos basada en una forma particular de illusio. En la relación entre el sistema de disposiciones producido total o parcialmente por la estructura y el funcionamiento del campo y el sistema de potencialidades objetivas ofrecidas por el campo, se define en cada caso el sistema de satisfacciones (realmente) deseables y se engendran las estrategias razonables inducidas por la lógica inmanente del juego [...]. El productor del valor de la obra de arte no es el artista sino el campo de producción como universo de creencia que produce el valor de la obra de arte como fetiche al producir la creencia en el poder creador del artista" (1995: 338-339).

4. Se trata del poema «L'albatros» de Les fleurs du mal, donde indica la última estrofa: «Le Poète est semblable au prince des nuées/ Qui hante la tempête et se rit de l'archer;/ Exilé sur le sol au milieu des huées,/ Ses ailes de géant l'empêchent de marcher» (1996: 36).

5. Aunque hay que aclarar que no toda la poesía de Julieta Dobles y de Alfonso Chase se ubica en ese eje solipsista. Textos como El libro de la patria (1976) o Los pies sobre la tierra (1978) de Chase y Los pasos terrestres (1976) de Dobles son escrituras que establecen relaciones concretas con la historicidad. 
6. Uno de sus autores, Carlos Francisco Monge, señalaba en 1999: "Las relaciones del Manifiesto trascendentalista con la historia presente son más difíciles de inventariar. Por lo que he visto, las generaciones más jóvenes han dedicado sus mejores esfuerzos a encontrar otras soluciones estéticas e ideológicas a sus creaciones, y salvo unos pocos casos, no han visto en el Manifiesto referencia alguna para su propia actividad. Tal vez las ideas han envejecido un poco; no lo puedo saber" (1999: 25-26).

7. Este énfasis originario es tomado de los principios de las poesías lírica y elegíaca griegas primitivas, especialmente del dístico elegíaco y de la poesía coral jónica. De esta última, Bowra afirma que: "Estos cantos solían honrar a los dioses y a las diosas, o celebraban la llegada de una estación del año o algún sitio sagrado" (1973: 42).

8. Señala Albán: "No soy un escritor, soy un poeta” (1973: 409).

9. Esta concepción ha sido leída por un sector de la crítica, incluso, como "iluminación" misma. Dice Alberto Baeza Flores: "Albán nos conquista porque su poesía es un redescubrimiento o un descubrimiento del ser" (1978: 303).

10. En el prólogo a Aun desde la lluvia titulado “Eros filial”, Julieta Dobles valida la obra de Zárate por su oposición con la poesía conversacional, estableciendo la dicotomía moda/valores humanos permanentes, donde el trascendentalismo ocuparía el segundo elemento de la oposición: "En efecto, Milton Zárate no se deja llevar por las modas de una poesía aprosada e irreverente. Él sabe que 'moda es lo que pasa' y sustenta su poesía en valores humanos permanentes. Fiel a los principios trascendentalistas, moldea el poema de forma tal, que siempre es un canto lleno de profundidad y belleza, sustentado en la originalidad y en el poder sugerente de las imágenes literarias" (2003: 10).

11. Al respecto, afirma Jorge Boccanera: "La poesía de Carlos Francisco Monge es existencia interrogada por medio de una constelación de símbolos -el agua, la ceniza, la historia- con los cuales interpela un devenir que es correntada, huracán sobre el mundo, al tiempo que trata de descifrar las claves de la destrucción en el balbuceo de los escombros" (2004: 203).

12. Así lo analiza, aunque con exceso retórico-metafísico, María Rosa de Bonilla en el prólogo a Cantares de la tierra: "Cuando hablamos de madurez poética queremos decir que las palabras, aquellas que nombran las cosas más profanas y cotidianas: viento, agua, corales, cafetos, piedra, alba, estrella, arcángel... dúctilmente amasadas con la savia creadora de Gabriela, conforman imágenes que trascienden el ajetreo cotidiano para llegar a la esencia de la vida; trascienden lo instintivo para llegar a lo sublime. Aladas, etéreas, se desprenden de su origen pragmático para visualizar lo universal y lo eterno" (1986: 7).

\section{Bibliografía}

\section{a) Textos poéticos}

Albán, Laureano. 1983. El viaje interminable. San José: Editorial Costa Rica.

1982. Geografía invisible de América. San José: Editorial Costa Rica.

Antillón, Ana. 1972. Demonio en caos. San José: Editorial Costa Rica. 
Ávila, Diana. 1981. Contracanto. Heredia: EUNA.

Azofeifa, Isaac Felipe. 1972. Poesía. San José: Editorial Costa Rica.

Baudelaire, Charles. 1996. Les fleurs du mal. Édition de Claude Pichois. Paris: Éditions Gallimard.

Bonilla, Rónald. 2001. Porque el tiempo no tiene sombra. San José: Editorial Costa Rica.

Braun, Juan Diego. 1990. “La mujer”. Lira costarricense. Máximo Fernández (comp.). Tomo I. San José: Editorial Universidad de Costa Rica, 59-63.

Brenes Mesén, Roberto. 1975. En el silencio. Poesías de Roberto Brenes Mesén. San José: Editorial Costa Rica, 31- 96.

1975. Hacia nuevos umbrales. Poesías de Roberto Brenes Mesén. San José: Editorial Costa Rica, 97- 117.

Castro, Alejandra. 2002. Hay milagros peores que la muerte. San José: Editorial Costa Rica. 2005. No sangres. San José: Editorial Costa Rica.

Charpentier, Jorge. 1989. Diferente al abismo y otros poemas. San José: Editorial Costa Rica.

Chavarría, Gabriela. 1986. Cantares de la tierra. San José: Editorial Costa Rica.

Cruz, Vivian. 2005. Vientre de ocarina. San José: Editorial Costa Rica.

Dobles, Julieta. 1993. Una viajera demasiado azul. San José: Editorial Costa Rica.

Fuentes, Laura. 1999. Penumbra de la paloma. San José: Ministerio de Cultura, Juventud y Deportes.

Marchena, Julián. 1973. "Vuelo supremo". Poesía contemporánea de Costa Rica. Carlos Rafael Duverrán (comp.). San José: Editorial Costa Rica, 47- 48.

Monge, Carlos Francisco. 2002. Enigmas de la imperfección. Heredia: EUNA.

Odio, Eunice. 1957. El tránsito de fuego. San Salvador: Ministerio de Cultura.

Quirós, Rodrigo. 1967. Después de nacer. San José: Editorial Costa Rica.

Segura, Ricardo. 1993. Ecos. San José: Editorial Costa Rica. 
Ulloa Barrenechea, Ricardo. 1970. Ángel del camino. San José: Imprenta Elena.

Ulloa Zamora, Alfonso. 1982. Antología personal. San José: Universidad Autónoma de Centroamérica.

Zárate, Milton. 2003. Aun desde la lluvia. San José: Editorial Costa Rica.

\section{b) Textos teóricos y críticos}

Albán, Laureano. 1973. “La estúpida poesía!”. Poesía contemporánea de Costa Rica. Carlos Rafael Duverrán (comp.). San José: Editorial Costa Rica, 406- 410.

Alonso, Dámaso. 1952. Poesía española, ensayo de métodos y límites estilísticos. Madrid: Editorial Gredos.

Baeza Flores, Alberto. 1978. Evolución de la poesía costarricense. San José: Editorial Costa Rica.

Benjamin, Walter. 1968. "The Work of Art in the Age of Mechanical Reproduction". Iluminations: Essays and Reflections. New York: Schoken Books, 217- 251.

Boccanera, Jorge. 2004. Voces tatuadas. Crónica de la poesía costarricense 1970-2004. San José: Ediciones Perro Azul.

Bolaños, Ligia. 1991. "Literatura: aproximaciones de lectura". Signos, lenguajes y discursos sociales. Antología de la cátedra de Comunicación y Lenguaje de la Escuela de Estudios Generales de la Universidad de Costa Rica. San José: Nueva Década, 59- 75.

Bowra, C. M. 1973. Historia de la literatura griega. Traducción de Alfonso Reyes. México: Fondo de Cultura Económica.

Bourdieu, Pierre. 1995. Las reglas del arte. Génesis y estructura del campo literario. Traducción de Thomas Kauf. Barcelona: Anagrama.

Cortés, Carlos. 1999. "La poesía costarricense de fin de siglo". Cuadernos Hispanoamericanos. 588 (junio): $37-44$ 
